\title{
The relation between seroma fluid and local recurrence after conservative breast surgery
}

\author{
Tarek A. El-Fayoumi, MD; Haytham Fayed, MD
}

Department of General Surgery, Alexandria University, Alexandria, Egypt.

Objectives: After conservative management of breast cancer, two third are at risk of local relapse, a risk which is largely reduced by radiotherapy. Seroma formation after mastectomy typically delays recovery and adds to morbidity.

Aim of the work: This study aims at collection of the seroma fluid after conservative breast surgery and detection of malignant cells in the drained fluid and its relation with local recurrence.

Methods: Twenty three patients with early breast cancer were included in the study and after conservative breast surgery. Seroma fluids were collected from the drain for detection of malignant cells then these patients were followed for twelve to twenty four months for detection of local recurrence

Results: There was a high significance in local recurrence associated with cases showing malignant second samples compared with those with negative one $\left(X^{2}=29.076, p=0.000\right)$.

Conclusions: Persistent presence of malignant cells in the postoperative drained fluid in females with early breast cancer is predictive for local recurrence. However long terms follow up and an increase in the number of the studied cases is recommended to confirm these results.

\section{Introduction:}

After conservative management of breast cancer, two third are at risk of local relapse, a risk which is largely reduced by radiotherapy. 1,2 Seroma formation after mastectomy typically delays recovery and adds to morbidity. ${ }^{3}$ Prognostic factors that influence breast cancer varies from many different clinical and histopathological criteria; definitely lymph nodes condition remains the most reliable one upon which depends further adjuvant therapy. ${ }^{4}$ The main target in surgical management of breast cancer is to obtain maximum chance of cure and to prevent local recurrence. ${ }^{1}$ Most common sites of local recurrence after mastectomy is the skin of the previous mastectomy, axilla and less commonly internal mammary, supraclavicular and infraclavicular nodes. ${ }^{5}$ There is no obvious mechanism that is accused in local recurrence but some claim that improper surgical technique by leaving residual tumor tissue or implanting malignant cells from blood vessels and lymphatics which are opened during surgery are concerned, however this is not common after conservative breast surgery as this is done by lumpectomy and detection of free safety margin by intra operative frozen section. ${ }^{6}$ Drains are channels that collect body fluids and blood after many operations. ${ }^{7}$ Draining the axillary field and the site of lumpectomy after breast conserving surgery is a way to collect postoperative secretions for cytological detection of malignant cells. The proper way of drainage is by active suction drain in order to avoid any residual fluids or cell collection. This study aims at collection of the seroma fluid after conservative breast surgery and detection of malignant cells in the drained fluid and its relation with local recurrence. ${ }^{8}$

\section{Patients and methods:}

The study included twenty three female patients with early breast cancer who were 
candidates for breast conservative surgery admitted to SurgicalOncology UnitAlexandria Main University Hospital. After taking their consent for the surgical plan of management, patients were subjected to history, clinical examination, laboratory investigations, mammography, ultrasonography of both breasts and cytological estimation and metastatic work out. Then breast conservative surgery was done for all patients with an intraoperative frozen section for detection of a histopathological negative safety margin and for diagnosis of clinically suspicious cases with a non- conclusive fine needle aspiration cytology. Then, closure of the lumpectomy site was performed followed by axillary dissection through a separate incision then a Redivac negative suction drain was applied. Postoperative collection and estimation of the volume of the drained fluid was performed. The drain was removed when the output was less than $30 \mathrm{ml} /$ day. ${ }^{9}$ Patients were given $100 \mathrm{mg}$ oral Sudan III in a piece of butter - a dye with high affinity to stain fat cells usually between the $3^{\text {rd }}$ and $5^{\text {th }}$ postoperative nights when the discharge was less bloody and still of moderate amount - and the color of the drainage was observed for change into orange. ${ }^{10}$ The drainage duration, daily amount and total amount were measured. Five $\mathrm{ml}$ samples of the drainage were taken on the 1st postoperative day and the day of drain removal then the sample was centrifuged and stained with $\mathrm{H}$ and $\mathrm{E}$ and submitted for cytological examination. The second samples were considered more reliable, as persistent presence of malignant cells in the samples lower the probability of false results. Follow up was done every three month for two years for morbidity, mortality and recurrence with correlation between the malignant cells in the drained fluid and local recurrence. Statistical analysis was done using SPSS, five percent was the level of statistical significance.

\section{Results:}

The mean age of the studied female patients ranged from 25 to 71 years with a mean of $49.69 \pm 8.97$ years. Breast mass was a constant complaint. The mean duration of symptoms was $4.04 \pm 2.61$ months (range from 1-12 months) the physical signs are presented in Table (1). 92.1\% of cases were diagnosed preoperative by fine needle as being malignant while the rest of cases were diagnosed during intraoperative lumpectomy and frozen section. After performing breast conserving surgery for all cases, the mean duration of drainage was $6.61 \pm 2.75$ days with an average of $4-13$ days and a mean of daily output of $77.78 \pm 31.95 \mathrm{ml}$ with an average of $40-160 \mathrm{ml}$ and a mean total output of $550.67 \pm 361.33 \mathrm{ml}$ with an average of 120 $1420 \mathrm{ml}$. Pathological examination revealed node negative in $30.3 \%$ of cases. Naked eye appearance of the drained fluid varied in color from serous, serosanguinuous and orange after the oral intake of Sudan III in all patients. However, microscopically revealed that majority of cells were inflammatory composed mainly of neutrophils with lymphocytes and histiocytes. Fat cells also were significantly higher in the second axillary samples than the first presenting $96.6 \%$ and $89.9 \%$ respectively $(\mathrm{X} 2=35.528, \mathrm{p}=0.000)$. Malignant cells in the form of clusters of viable epithelial cells with large pleomorphic hyperchromic nuclei and acidophilic cytoplasm were present in $14.6 \%$ of cases from the first samples and $20.2 \%$ had malignant first axillary samples. Only $15.7 \%$ showed persistent malignant second samples: $4.5 \%$ breast samples and $11.2 \%$ axillary samples. There was a statistically significant difference between the lower malignant second samples and the first one $(\mathrm{X} 2=17.100, \mathrm{p}=0.000)$. None of the nodal negative patients had malignant cells in the fluid drained. Also cases with malignant second samples had significant more higher mean number of involved and dissected lymph nodes $(7.86 \pm 3.13$ Vs 1.56 $\pm 1.99)(\mathrm{t}=9.819, \mathrm{p}=0.000)$ and $(24.36$ \pm 4.634 Vs $11.59 \pm 3.03)(\mathrm{t}=13,21, \mathrm{p}=0.000)$ respectively.

A range of follow up 24-48 months showed local recurrence in $10.1 \%$ of cases: $66.7 \%$ axillary and $33.3 \%$ breast with a mean duration of recurrence $41.22 \pm 9.52$ month, tumor characteristics and its relation to local recurrence are presented in Table (1). There 
Table I: local recurrence and its relation with clinical and histopathological features of the tumor.

\begin{tabular}{|c|c|c|c|c|c|}
\hline Features of tumor & $\begin{array}{c}\text { Absence } \\
\text { of local } \\
\text { recurrence } \\
89.9 \%\end{array}$ & $\begin{array}{l}\text { With local } \\
\text { recurrence } \\
10.1 \%\end{array}$ & $\mathrm{X} 2$ & $\mathrm{p}$ & Total 100\% \\
\hline $\begin{array}{l}\text { Site: } \\
\text { Upper outer } \\
\text { Upper inner } \\
\text { Lower outer } \\
\text { Lower inner } \\
\text { Central }\end{array}$ & $\begin{array}{l}55 \% \\
27.5 \% \\
6.3 \% \\
3.8 \% \\
7.5 \% \\
\end{array}$ & $\begin{array}{l}77.8 \% \\
11.1 \% \\
11.1 \% \\
0 \\
0\end{array}$ & - & - & \begin{tabular}{|l|}
$57.3 \%$ \\
$6.7 \%$ \\
$25.8 \%$ \\
$3.4 \%$ \\
$6.7 \%$ \\
\end{tabular} \\
\hline Size & $3.86+1.83$ & $4.67+0.50$ & 1.144 & 0.265 & $4.03+1.75$ \\
\hline $\begin{array}{l}\text { Side: } \\
\text { Right } \\
\text { Left } \\
\end{array}$ & $\begin{array}{l}38.3 \% \\
63.1 \% \\
\end{array}$ & $\begin{array}{l}55.6 \% \\
44.4 \% \\
\end{array}$ & 0.949 & 0.266 & \begin{tabular}{|l}
$40.4 \%$ \\
$59.6 \%$ \\
\end{tabular} \\
\hline $\begin{array}{l}\text { Lymph nodes in axilla: } \\
\text { Negative } \\
\text { Positive }\end{array}$ & $\begin{array}{l}40 \% \\
60 \% \\
\end{array}$ & $\begin{array}{l}0 \\
100 \% \\
\end{array}$ & 0.251 & 0.018 & $\begin{array}{l}36 \% \\
64 \% \\
\end{array}$ \\
\hline $\begin{array}{l}\text { Pathology: } \\
\text { - Infiltrating ductal } \\
\text { carcinoma } \\
\text { - Infiltrating lobular } \\
\text { carcinoma } \\
\end{array}$ & $\begin{array}{l}92.5 \% \\
7.5 \% \\
\end{array}$ & $\begin{array}{l}88.9 \% \\
11.1 \% \\
\end{array}$ & 0.146 & 0.539 & $\begin{array}{l}92.1 \% \\
7.9 \% \\
\end{array}$ \\
\hline $\begin{array}{l}\text { Stage A } \\
\text { Stage B1 } \\
\text { Stage B2 } \\
\end{array}$ & $\begin{array}{l}7.5 \% \\
25 \% \\
67.5 \% \\
\end{array}$ & $\begin{array}{l}0 \\
0 \\
100 \% \\
\end{array}$ & 4.132 & 0.127 & \begin{tabular}{|l|}
$6.7 \%$ \\
$22.5 \%$ \\
$70.8 \%$ \\
\end{tabular} \\
\hline $\begin{array}{l}\text { Grade I } \\
\text { Grade II } \\
\text { Grade III }\end{array}$ & $\begin{array}{l}13.7 \% \\
68.8 \% \\
17.5 \%\end{array}$ & $\begin{array}{l}0 \\
33.3 \% \\
66.7 \%\end{array}$ & 11.49 & 0.003 & $\begin{array}{l}12.4 \% \\
65.2 \% \\
22.4 \% \\
\end{array}$ \\
\hline $\begin{array}{l}\text { Axillary nodes } \\
\text { None } \\
\text { positive } \\
\end{array}$ & $\begin{array}{l}33.6 \% \\
66.6 \% \\
\end{array}$ & $\begin{array}{l}0 \\
100 \% \\
\end{array}$ & 4.306 & 0.032 & $\begin{array}{l}30.3 \% \\
69.7 \% \\
\end{array}$ \\
\hline
\end{tabular}

was a high significance in local recurrence associated with cases showing malignant second samples compared with those with negative one $(50 \%$ Vs $2.7 \%)(\mathrm{X} 2=29.076$, $\mathrm{p}=0.000)$.

\section{Discussion:}

The prediction of local recurrence after surgical management of breast cancer is difficult despite the clinical knowledge about the disease. Early diagnosis, the number of microscopic and macroscopic lymph node affection, proper staging and histopathological type and grade, proper surgical management with the proper selection of the adjuvant therapy are the feasible predictive factors. ${ }^{6}$ The old belief that the more extensive surgical excision and aggressive radiotherapy the more curability is not nowadays the rule, this is because during operation opening of blood vessels and lymphatics allow field contamination with lymph and blood harboring malignant cells and that local recurrence occur from this cause rather than inadequate surgical removal. ${ }^{6}$ The present study included twenty three patients in which we tried to trace the malignant cells after conservative breast 
surgery by taking drain samples from the breast and axilla with special precautions in the technique as they were transmitted freshly to the pathological examination for detection of malignant cells. We considered the second samples as more reliable - the first sample was discarded as it was considered as operative field wash out from the shaded and floating malignant cells which may result from transgression of malignant tissue- they were taken long duration postoperative on the day of drain removal in ordered to give chance for the floating cells to clear, then after that time the discharge may be associated with continuous source of viable malignant cells. The color of drained fluid turned from serous to serosanguinuous into orange after oral admission of Sudan III which is due to staining of fat cells. Definitely these fat cells are from the crashed lymphatic vessels contained in the lymphatic fluid that are the main source of postoperative discharge which might contain malignant cells. In a study done by Boolsen et al ${ }^{11}$ they found that the drained fluid collected postoperative is not an accumulation of serum but exudates. Another study by Bonnema et al ${ }^{12}$ comparing the composition of the drained fluid with the constituents of blood and peripheral lymph and found that after the first postoperative day the drainage changed into lymph like fluid. These two studies support the theory of the leakage of lymphatic as a probable source of malignant cells in the drainage. Vujicic et $\mathrm{al}^{6}$ reported the presence of malignant cells in the postoperative seroma but without talking about local recurrence, this study was performed on 142 female patients with breast cancer treated by radical mastectomy, the aspirated seroma on the sixth postoperative day where malignant cells in $22.5 \%$ of cases and appeared as isolated cells, with some noted degenerative changes. In our study malignant cells were detected in $15.7 \%$ of cases in the form of groups of malignant epithelial cells, this may be attributed to the fresh sample taken from the draining tubes rather than puncturing old seroma fluid after six days. Puncturing the seroma may yield only the separated, floating, degenerating and nonresident cells, but malignant cells forming groups might be deeply seated, stuck to the seroma wall or laying inside septations.

The larger the number of involved lymph nodes the more the malignant cells studied in the lymphatics released in the axilla when dissected and significantly correlating with malignant second samples. Also the number of dissected lymph nodes reflects the radicality in the axillary dissection and consequently more lymphatic vessels injured and more lymphatic vessels postoperative, this theory is also supported by absence of malignant cells in the drainage when the patient is node negative.

A study done by Mady ${ }^{13}$ comparing two groups of patients with early breast cancer where twenty did breast conservative surgery and the other twenty did modified radical mastectomy they found that the incidence of malignant cells in axillary drainage was the same in both groups, there was an incidence of malignant cells and axillary recurrence in six cases due to lymphatic leak from the interrupted axillary lymphatic vessels during dissection. Dissection is associated with transection of some lymphatics of the arm and the arm movements act as pump that forces lymph, probably with malignant cells, into empty axillary fossae. ${ }^{14}$

The malignant second sample was significantly correlating the local recurrence. This relation could be explained by the fact that the radicality in surgery or adjuvant therapy does not sterilize the field from malignant cells. Residual malignant cells might become dormant and suppressed by the immune system, it becomes compromised allowing a chance for these cells to proliferate into local recurrence which may explain its late occurrence in this study. In conclusion persistent presence of malignant cells in the postoperative drained fluid in females with early breast cancer is predictive for local recurrence. However long terms follow up and an increase in the number of the studied cases is recommended to confirm these results

\section{Reference}

1- Whipp E, Beresford M, Sawyer E, Halliwell 
M: True local recurrence rate in the conserved breast after magnetic resonance imagingtargeted radiotherapy. International Journal of Radiation 2010; 76: 984-990.

2- Pogson CJ, Adwani A, Ebbs SR: Seroma following breast cancer surgery. Eur J Surg Oncol. 2003; 29(9): 711-717.

3- Loo WT, Chow LWC: Factors predicting seroma formation after mastectomy for Chinese breast cancer patients. Indian Journal of Cancer. 2007; 44: 99-103.

4- Sosa A, Dinner W, Gausser Y, Choti M, Langer JR: Association between extent of axillary lymph node dissection and survival in patients with stage 1 breast cancer. Ann Surg Oncol 1998, 5:140-149.

5- Merten D, Allen S, Lori J. (eds): Clinical oncology. $2^{\text {nd }}$ ed. London Livingstone. 2000; 75.

6- Vujicie N, Dominis M, Rogan-Gras J, Note P: The significance of cancer cell contaminating postoperative seroma. Clin Exp Metastasis 1986; 4: 221-227.

7- Kirk R: Handling drains. In: Basic surgical technique. Kirk ed: $4^{\text {th }}$ ed London Livingstone. 2000; 23-57.

8- Woodward WA, Strom EA, Tacker SL: Changes in the 2003 American Joint
Committee on Cancer staging for breast cancer dramatically affect stage-specific survival. J Clin Oncol 2003; 21: 3244-3248.

9- Philip A, Marilee F, Stephan D: Seroma formation after breast cancer: Incidence and predicting factors. Ann J Surg 1997; 173: 76-79.

10- Mostafa M: evaluation of postsplenectomy closed suction drainage a clinical, biological and bacteriological study. MS thesis. University of Alexandria Faculty of Medicine 1999; 46.

11- Bolseen S, Nilsen VB, Jensen I, Brik S: Postmastectomy seroma. A study of the nature and origin of seroma after mastectomy. Dan Med Bull 1989; 36: 487-489.

12- Bonema J, Ligtenstein DA, Wiggerst, Van Geed AN: The composition of serrous fluid after axillary dissection. Eur J Surg 1999; 165: 9-13.

13- Mady RF: Cytological evaluation of malignant cells in drained fluid after breast surgery for malignant lesions. MS thesis. University of Alexandria Faculty of Medicine 2002; 78.

14- Zintel HA, Nay HR: Postoperative complication of radical mastectomy. Surg Clin North Am 1984; 44: 313-323. 